\title{
The Role Of Human Resources Investment On Economic Growth In Riau Province
}

\author{
Emrizal Pakis*, M. Umar Burhan*, Ghozali Maski*, Moh. Khusaini* \\ *(Economics, University of Brawijaya, Indonesia)
}

\begin{abstract}
Economic growth is a critical success factor of economic development in a country. Some of the factors that affect economic growth include natural resources (SDA), human resources (SDM), physical investment, and household consumption. Natural resources (SDA) as one of the basic limited variables in the production thus require an investment to improve their products. Communities that have qualified human resources (SDM) will create higher productivity and correlated to the increase on income leads to purchasing power (consumption) and eventually boost regional economic growth. This research aims at investigating and analyzing the effect of human resources investment, physical investment, human resources and household consumption on economic growth in the Province of Riau. This research was conducted by using path analysis with Smart PLS program. The results demonstrate comprehensively that physical investment, human resources $(S D M)$, household consumption has a positive effect on economic growth in the province of Riau except natural resources (SDA) that negatively affect on economic growth in the province of Riau.
\end{abstract}

Keywords: Human Resource Investment, Natural Resources, Physical Investment and Economic Growth.

\section{Introduction}

Regional economic resource potential can be defined as all the resources at its disposal both belonging to the natural resources (SDA) / endowment factors and potential human resources (SDM) that can provide benefits and can be used as the basis of development of capital (economic) region. Development of a region is affected by many factors, including, natural resources (SDA), human resources (SDM), physical investment, government spending and private and other conditions.

Besides natural resources, the role of human resources within the context of the economic development activities becomes more significant. As expressed by Smith, available natural resources (SDA) are the basis of the production activities. Then he assumes that humans as a primary factor of production determine the wealth of nations. It is also stated by Richardo assume that the number of factors of production land (natural resources) can not grow, therefore they eventually become a limiting factor. In Malthus' perspective, limited natural resources (SDA) will not be able support the growth of population due to the production of natural resources (SDA) will experience what is known as the diminishing return (Arsyad, 2004 and Mulyadi, 2003).

Clark (1940) expressed that when the economy is at a high level, the proportion of labor associated with the primary sector (agriculture, plantation, and mining) decreased, where the proportion of employment in the secondary sector (processing, manufacturing and construction) increased to certain level. Furthermore the proportion of labor force in the tertiary sector (transportation and communication, trade, government, healthcare, education, and other services activities) increased after the primary sector and secondary sector has reached equilibrium. The changes in the proportion of workers in each sector shows that the HR movement would occur from the primary sector to the secondary sector and the tertiary sector because of differences in labor productivity and technological advances in each activity (Adisasmita, 2011).

Based on these arguments, the natural resources (SDA) is the raw material for the engine of economic growth, however if the natural resources (SDA) could not be managed properly by qualified human resources (SDM), it can reduce the value-added of economic growth in a region. This is appropriate according to the results of studies by Lucas (1988), Romer (1989), Galor and Weil (2000) that human capital is considered as an important factor for economic growth (Zanden and Marks, 2012).

Thus it can be concluded there is gap between natural resources (SDA) with human resources (SDM). In the short-term natural resources (SDM) of a region could be an important resources to produce some products that are needed by the population. But in the long term diminishing return occurs due to the use of natural resources (SDA) and mining land has diminished. Therefore, economic development in Riau Province was necessarily rely on human resources (SDM).

One of the conditions of human resources (SDM) in the province of Riau, can be shown from the population growth rate, where the condition is relatively high in 2011 with 3.61 percent and is above the average growth of 1.3 percent of Indonesia's population. Increasing population growth rate in the province of Riau is also accompanied by a decrease in the poverty rate which declined 9.48 percent in 2009 to 8.17 percent in 2011 . 
In 2009 and 2011 economic growth in Riau Province is increasing, where the ratio between non-oil economic growth is higher than in the oil and gas, respectively by 7.63 and 5.01 percent. Following, the distribution of the Agricultural Sector GDP at current prices (percent) from 2009 to 2011, there is a decline in year to year. Meanwhile, there is a positive correlation between economic growth and human development index. This indicates the existence of quality human resource leverage to economic growth in the province of Riau.

Table 1. Macroeconomic Conditions Riau Province, Year 2009-2011

\begin{tabular}{|c|c|c|c|c|}
\hline \multirow{2}{*}{ No } & \multirow{2}{*}{ Indicator } & \multicolumn{3}{|c|}{ Year } \\
\hline & & 2009 & 2010 & 2011 \\
\hline 1 & The rate of population growth (percent) & 2,26 & 4,37 & 3,61 \\
\hline 2 & Human Development Index & 75,60 & 76,07 & 76,53 \\
\hline 3 & Poverty (percent) & 9,48 & 8,47 & 8,17 \\
\hline 4 & $\begin{array}{l}\text { Distribution of the Agricultural Sector GDP at } \\
\text { current prices (percent) }\end{array}$ & 20,28 & 19,97 & 18,87 \\
\hline 5 & $\begin{array}{l}\text { Economic Growth With Gas At Constant Prices } \\
2000\end{array}$ & 2,97 & 4,17 & 5,01 \\
\hline 6 & Economic Growth Without Oil & 6,56 & 7,16 & 7,63 \\
\hline 7 & Economic Growth With Gas & 2,97 & 4,17 & 5,01 \\
\hline
\end{tabular}

Source: BPS Riau Province

Based on the background above, This research aims at investigating and analyzing the effect of human resources investment, physical investment, human resources (SDM) and household consumption on economic growth in the Province of Riau.

\section{Research Methods}

The research was conducted in the province of Riau, Indonesia in 2006 until 2011. The analytical technique used is path analysis, which examined the theorized causal (Riduwan and Kuncoro, 2008). This test investigate the influence between constructs, both the direct effect and indirect effect. The variables used in the study are as the following.

Table 2.Variable and Subvariable Used in this Research

\begin{tabular}{|c|c|c|c|c|}
\hline No & Variable & Sub Variable & $\begin{array}{c}\text { Scale } \\
\text { Measurement }\end{array}$ & $\begin{array}{c}\text { Unit of } \\
\text { Measure }\end{array}$ \\
\hline 1 & Economic Growth $(\mathrm{Z})$ & GDP constan year $2000\left(\mathrm{Z}_{1}\right)$ & Ratio & Rupiah (Rp) \\
\hline \multirow{2}{*}{2} & \multirow{2}{*}{$\begin{array}{l}\text { Human Resources - SDM } \\
\text { (Y) }\end{array}$} & Education $\left(\mathrm{Y}_{1}\right)$ & Ratio & Persentase \\
\hline & & Health $\left(\mathrm{Y}_{2}\right)$ & & \\
\hline \multirow{5}{*}{3} & \multirow{5}{*}{$\begin{array}{l}\text { Natural Resources - SDA } \\
\left(\mathrm{X}_{1}\right)\end{array}$} & TBS/ Oil Palm $\left(X_{11}\right)$ & Ratio & Rupiah (Rp) \\
\hline & & Rubber $\left(\mathrm{X}_{12}\right)$ & Ratio & Rupiah (Rp) \\
\hline & & Coconut $\left(\mathrm{X}_{13}\right)$ & Ratio & Rupiah (Rp) \\
\hline & & $\operatorname{Coal}\left(\mathrm{X}_{14}\right)$ & Ratio & Rupiah (Rp) \\
\hline & & $\operatorname{Oil}\left(\mathrm{X}_{15}\right)$ & Ratio & Rupiah (Rp) \\
\hline \multirow{2}{*}{4} & \multirow{2}{*}{ Physical Investment $\left(\mathrm{X}_{2}\right)$} & Domestic Investment $\left(\mathrm{X}_{21}\right)$ & Ratio & Rupiah (Rp) \\
\hline & & Foreign Investment $\left(\mathrm{X}_{22}\right)$ & Ratio & Rupiah (Rp) \\
\hline
\end{tabular}

\section{Empirical Results}

Based on the PLS test results, $\mathrm{R}^{2}$ values for economic growth rate is 0.5223 , this means economic growth simultaneously influenced by natural resources (SDA) physical investment, human resources (SDM) and the role of household consumption by 52.23 percent. While the remaining 47.77 percent are caused by other variables. Dominant influence (30.3 percent) in promoting economic growth in the province of Riau is human resources (SDM). The further details can be seen in the following figure.

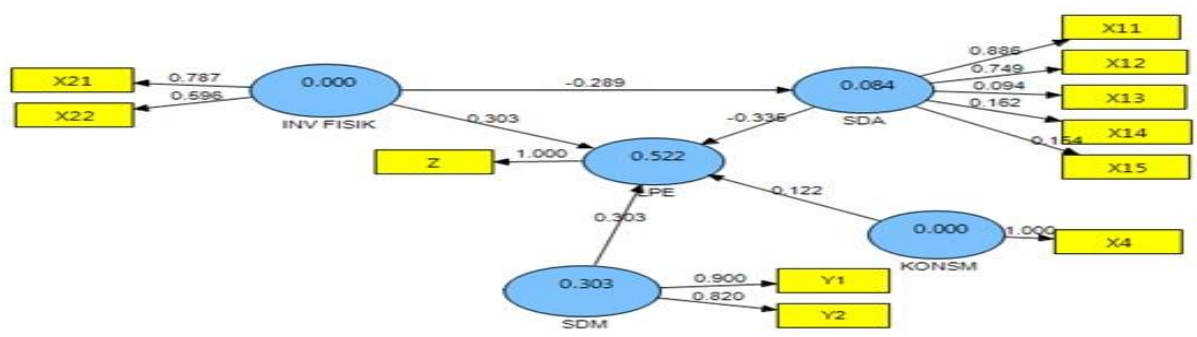

Fig 1. The impact of Natural Resources, Physical Investment and Household Consumption on Source : Smart PLS Economic Growth 
The hypothesis of this research, there is comprehensively a positive effect of natural resources, physical investment, human capital investment and household consumption on economic growth in the province of Riau. The results of hypothesis testing are as follows:

a. The influence of natural resources (SDA) on economic growth is negative by 33,54 percent with the t-value is 5.025, so that Ha rejected.

b. Impact of physical investment to economic growth is positive at 30.28 percent and the t-value is 3.163 , so that $\mathrm{Ha}$ is accepted

c. The influence of HR on economic growth is positive at 30.30 percent and the t-value is 4.325 so that Ha is accepted

d. The Influence of household consumption to economic growth is positive at 12.20 percent and the t-value is 1.97 so that Ha is accepted.

Table 3. Path Coefficients

\begin{tabular}{|l||c|c|c|c|}
\hline & Original Sample (O) & $\begin{array}{c}\text { Standard Deviation } \\
(\text { STDEV })\end{array}$ & $\begin{array}{c}\text { T Statistics } \\
(\mid \text { O/STERR })\end{array}$ & Desc. \\
\hline FISIK -> LPE & 0.302751 & 0.088076 & 3.437387 & Sig \\
\hline FISIK -> SDA & -0.289385 & 0.091491 & 3.162999 & Sig \\
\hline KONSM -> LPE & 0.122046 & 0.061981 & 1.969091 & Sig \\
\hline SDA -> LPE & -0.335351 & 0.066735 & 5.025077 & Sig \\
\hline SDM -> LPE & 0.302757 & 0.070007 & 4.324681 & Sig \\
\hline
\end{tabular}

Source: Smart PLS.

Table 4. Output Total Variable Testing Mediation Effects

\begin{tabular}{|l|c|c|c|}
\hline & Original Sample (O) & Standard Deviation (STDEV) & $\begin{array}{c}\text { T Statistics } \\
(|\mathrm{O} / \mathrm{STERR}|)\end{array}$ \\
\hline FISIK -> LPE & 0.399796 & 0.099340 & 4.024520 \\
\hline
\end{tabular}

Source: Smart PLS

The region of Riau which is strategic and has many natural resources, make investment opportunities are quite wide and have positive implications in the form of relatively high economic growth. Although the global economic crisis hit the global financial crisis, but the rate of economic growth of Riau is still above average in Indonesia. Economic Growth Rate (LPE) nationwide in 2008 which is about 8.06 percent while the national average of 6.01 percent. This illustrates the economic base is relatively strong because Riau province can not be separated from the role of three keys strategic sectors, namely agriculture, industry, and trade.

The positive influence of physical investment on economic growth in accordance with the expression by Harold Domar (Kuncoro, 2006) that investment always has double effect, on the one hand it directly affects the aggregate demand and on the other hand affects the production capacity due to the accumulation of capital to add or increase later production or income. Physical investment that grows and thrive in the province of Riau generally in the form of natural resource management in the mining sector as well as in agriculture or plantations. Besides investing in primarily industrial processing of natural resources, there is also investment in infrastructure as support to other investments.

Besides, the investment influences the employment in agriculture, industry, trade and other services sectors. With the investment, surely it will certainly encourage the creation of employment opportunities, which in turn increases the economy's output. The effect of investment on employment in appropriate accordance with the theory expressed by Rostow (in Todaro, 2000) which states that any attempt to take-off requires the mobilization of domestic savings and foreign savings to create a considerable investment, to accelerate economic growth, which in turn will increase employment opportunities and welfare of the community as a consequence of the increase in earned income communities.

Table 5. Domestic and Foreign Investment Value of Riau Province Year 2009-2011 (in billion Rupiah)

\begin{tabular}{|c|c|c|c|c|c|c|c|}
\hline \multirow[t]{2}{*}{ No. } & \multirow[t]{2}{*}{ Province } & \multicolumn{3}{|c|}{$\begin{array}{c}\text { Domestic Investment Value (Billion } \\
\text { Rupiah) }\end{array}$} & \multicolumn{3}{|c|}{$\begin{array}{l}\text { Foreign Direct Investment Value (U.S. \$ } \\
\text { Million Rupiah) }\end{array}$} \\
\hline & & 2009 & 2010 & 2011 & 2009 & 2010 & 2011 \\
\hline 1 & Riau & $3.386,0$ & $1.037,1$ & $7.462,6$ & 251,6 & 86,6 & 212,3 \\
\hline
\end{tabular}

Source: BPS Riau Province

Generally, the economic growth without the oil and gas at Riau Province is higher than the economic growth oil and gas. In the years 2007-2011 there has been a couple of times increasing in world oil prices, while the growth rate of oil production could not follow the acceleration of oil needs so that the government implemented a policy of increasing prices of fuel oil (BBM) which in turn affect domestic economic activity and national economic activity (Bappeda Riau, 2012). 


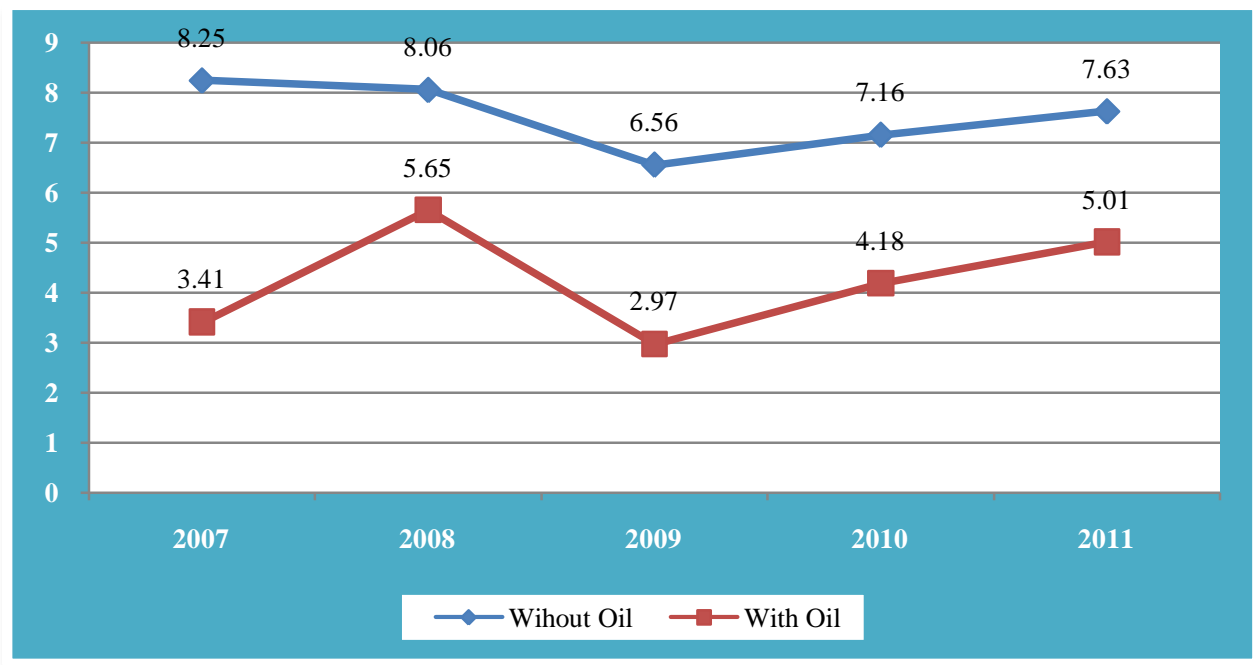

Sources: Bappeda Riau Province

Fig 2. Riau Economic Growth, Year 2007-2011

Furthermore, during the years 2007-2011, the rate of economic growth is relatively stable although the Riau Province was in the turmoil period of palm commodity prices which was declining and then drop until the lowest point and this condition began at the end of 2008. It is also influenced by the global economic crisis. Achievement of the Riau economic growth rate in 2011 is closely related to the better performance results on sectoral activity. The highest growth by sector, are in construction and trade, hotels and restaurants. The preparation of the $18^{\text {th }}$ PON (national sporting competitions) in the Riau was the host held in 2012 so coloring Riau's economy. It could be seen by the growth of the construction sector is very dominant in this year. The more passionate attempt by sectoral progress in economic impacts conducively to the development of the building sector.

In general, the progress of the economy could trigger the acceleration of revenues, among others, to the factors of production such as labor income, increased purchasing power resulting in soaring demand such as residential buildings, either new or renovation demands and even aimed for investment. This as stated by Harrod-Domar that if you want to grow, the economy should invest because the real economic growth rate actually depends on the productivity of investment.

Table 6. Riau Economic Growth Without Oil on Constant 2000 Market Prices, Years 2007-2011 (percent)

\begin{tabular}{|c|c|c|c|c|c|}
\hline Sector & 2007 & 2008 & 2009 & 2010 & 2011 \\
\hline 1. Agriculture & 4,84 & 4,79 & 3,72 & 3,95 & 3,88 \\
\hline 2. Mining & 24,57 & 18,13 & 13,23 & 9,73 & 13,18 \\
\hline 3. Industry & 11,41 & 8,98 & 6,36 & 7,67 & 8,09 \\
\hline 4. Electricity and water & 5,62 & 6,86 & 3,17 & 5,59 & 6,85 \\
\hline 5. Building & 11,65 & 11,14 & 8,77 & 8,84 & 12,77 \\
\hline 6. $\quad$ Trading & 8,94 & 9,72 & 8,87 & 10,17 & 10,09 \\
\hline 7. Transportation & 7,28 & 10,45 & 8,26 & 9,43 & 9,73 \\
\hline 8. Finance & 13,33 & 13,65 & 10,14 & 9,61 & 9,67 \\
\hline 9. Services & 9,71 & 9,25 & 8,54 & 8,44 & 8,48 \\
\hline Economic Growth & 8,25 & 8,06 & 6,56 & 7,16 & 7,63 \\
\hline
\end{tabular}

Sources: BPS Riau Province

The development of the trade sector in Riau is very promising from various aspects such as the pretty good purchasing power of Riau citizen mainly from agro-industry, infrastructure as well as the business continues to grow rapidly. House-store construction grows in each location of new business, the business location could be in urban and non-urban areas. As stated by Karl Bucher, economic development includes the production stage for its own needs, stage of the city's economy because the exchange between the city's economy. In the exchange expansion stage of the city's economy into the national economy, role of the merchant becomes very important (Arsyad, 2004).

One of the growth drivers of the growing trade subsector is the improvement of buying and selling transactions in goods and services, especially durable goods (durable goods), such as electrical goods and motor vehicles. The large number of vehicles coming into the Riau positively correlated boost the trade transactions. So do with the increasing demand of various brands of four-wheel vehicles which is very high. In addition, high 
growth also occurred in the non-oil mining sector especially high contribution level of coal production. Although the grothw is high but the level of production tends to decline.

The next highest growth occurred in the transportation and communication sector then the financial sector and leasing and services company. Growth rate obtained was related to the carrying capacity of the availability of infrastructure that are the result of the development program, especially road and bridge infrastructure improvements that facilitate also open the access and transportation to all areas in Riau province. In line with the adequate public transportation facilities, as indicated by the demand for cars in terms of trade as a means of land transport increased rapidly, especially car rentals and travel between regions, in addition there is also a transport of freight. Business of goods delivery is growing rapidly along with the increasing of need for the distribution of goods to any corners.

Riau's economy structure without oil in thear of 2011 was still dominated by three sectors including agriculture, industry, and trade.

Table 7. Gas Distribution Without the Riau GDP at Current Prices, 2007-2011 (percent)

\begin{tabular}{|c|c|c|c|c|c|}
\hline Sektor & 2007 & 2008 & 2009 & 2010 & 2011 \\
\hline 1. Agriculture & 37,25 & 35.63 & 33,66 & 32,17 & 30,78 \\
\hline 2. Mining & 1.72 & 2.02 & 2,33 & 2,36 & 2,49 \\
\hline 3. Industry & 30.16 & 29.29 & 28,88 & 28,05 & 27,03 \\
\hline 4. Electricity and water & 0.34 & 0.31 & 0,29 & 0,27 & 0,29 \\
\hline 5. Building & 6,02 & 7.58 & 8,24 & 8,98 & 10,16 \\
\hline 6. $\quad$ Trading & 12,02 & 12.95 & 13,90 & 15,04 & 15,89 \\
\hline 7. Transportation & 3.29 & 3.26 & 3,22 & 3,13 & 3,09 \\
\hline 8. $\quad$ Finance & 3.35 & 3.40 & 3,71 & 3,94 & 4,14 \\
\hline 9. Services & 5,86 & 5.55 & 5,77 & 6,05 & 6,13 \\
\hline Tot a l & 100.00 & 100.00 & 100.00 & 100.00 & 100.00 \\
\hline
\end{tabular}

Sources: BPS Riau Province

The most contribution in the economy of Riau is agricultural sector with forestry subsector. In 20072011 these subsectors tend to decrease. Besides plantation sub-sector also showed a trend to going down. This condition is affected by limitations in the development of the plantation business and phenomenon of oil prices weakening in the final quarter of 2008 until reaching the lowest price point at the some of the time in 2009 , so that showed the contribution which are weakening when compared to the price of oil at the stable situation. Despite there was a decline in contributions, but these two sub-sectors still have a significant role in the contribution of the agricultural sector.

As stated by Smith, available natural resources (SDA) are fundamental for production activities. Amount of available natural resources (SDA) is a maximum limit to the economic growth. By Malthus, limited natural resources (SDA) will not be able to support the population growth due to the natural resources (SDA) production will experience what is known as the diminishing return (Arsyad, 2004 and Mulyadi, 2003).

Table 8. Development of Economic Growth in Riau Seen from the Side Expenditures During the Year 2009-2011

\begin{tabular}{|c|c|c|c|c|c|c|}
\hline \multirow{2}{*}{ Details } & \multicolumn{3}{|c|}{ Without Oil } & \multicolumn{3}{|c|}{ By Oil and Gas } \\
\hline & 2009 & 2010 & 2011 & 2009 & 2010 & 2011 \\
\hline 1. Household Consumption & 8,88 & 8,23 & 6,68 & 8,88 & 8,23 & 6,68 \\
\hline $\begin{array}{l}\text { 2. Private consumption Nir Profit } \\
\text { Institutions }\end{array}$ & 18,92 & $-1,30$ & 6,43 & 18,92 & $-1,30$ & 6,43 \\
\hline 3. Government Consumption & 8,88 & 1,70 & 1,89 & 8,88 & 1,70 & 1,89 \\
\hline 4. Gross Fixed Capital Formation (PMTB) & 4,13 & 14,18 & 9,81 & 9,02 & 8,42 & 8,36 \\
\hline 5. Changes in Stock & - & - & - & - & - & - \\
\hline 6. Export & 1,83 & 4,00 & 10,46 & $-3,78$ & 3,76 & 3,08 \\
\hline 7. Import & 5,10 & 8,43 & 6,08 & 1,02 & 8,75 & 5,78 \\
\hline Riau & 6,44 & 7,16 & 7,63 & 2,90 & 4,17 & 5,01 \\
\hline
\end{tabular}

Sources: BPS Riau Province

It may be noted above that the development of Riau economic growth in terms of expenditure during the period 2009-2011, generally each component showed an increase compared to the previous year. However, there are some components that the growth is slowing. In 2011 (excluding oil and gas) household consumption component can grow quite high because the material is not sustained by the food. This shows people's purchasing power is still good despite high inflation rate in Riau. This indicates that the nominal income of the people has increased and is able to follow the rate of inflation, so that the rate of growth of this component increased slightly over the previous year. 
The Role Of Human Resources Investment On Economic Growth In Riau

Table 9. Percentage Distribution of GDP Riau Seen from the Side Expenditures During the Year 2009-2011 Based on Constant 2000

\begin{tabular}{|c|c|c|c|c|c|c|}
\hline \multirow{2}{*}{ Description } & \multicolumn{3}{|c|}{ Without oil } & \multicolumn{3}{|c|}{ WIth oil } \\
\hline & 2009 & 2010 & 2011 & 2009 & 2010 & 2011 \\
\hline Household Consumption & 73,06 & 73,79 & 73,13 & 30,68 & 32,92 & 31,00 \\
\hline a.Food & 25,02 & 24,98 & 24,69 & 12,60 & 13,68 & 12,88 \\
\hline b. Non Food & 48,04 & 48,81 & 48,44 & 18,08 & 19,25 & 18,11 \\
\hline $\begin{array}{ll}2 . & \text { Private consumption Nir Profit } \\
& \text { Institutions } \\
\end{array}$ & 0,59 & 0,55 & 0,54 & 0,29 & 0,29 & 0,28 \\
\hline 3. $\quad$ Government Consumption & 11,94 & 11,33 & 10,72 & 7,37 & 7,52 & 6,41 \\
\hline $\begin{array}{ll}4 . & \text { Gross Fixed Capital Formation } \\
\text { (PMTB) }\end{array}$ & 26,27 & 27,99 & 28,56 & 24,50 & 25,72 & 24,55 \\
\hline 5. $\quad$ Changes in Stock & 0,82 & 27,99 & $-0,25$ & 2,60 & 1,78 & 2,56 \\
\hline 6. $\quad$ Export & 46,33 & 44,96 & 46,14 & 50,08 & 47,40 & 49,47 \\
\hline 7. Import & 59,01 & 59,71 & 58,85 & 15,53 & 15,63 & 14,26 \\
\hline Riau & 100 & 100 & 100 & 100 & 100 & 100 \\
\hline
\end{tabular}

Sources: BPS Riau Province

Contribution of household consumption component in GDP structure was dominating at 2009-2011 in Riau by expenditure component. This shows that change in this component will have a major impact on economic fluctuations Riau in general. Growth in the private nonprofit organization consumption was 18.92 percent in 2009 and decreased to 6.43 percent in 2011. This is caused by private nonprofit institutions activities such as civil society organizations, political organizations, and religious organizations also increased in 2009.

Based on the analysis of research that the impact of people's consumption may increase due to the economic growth of 12.20 percent. This is in accordance with the disclosure of Keynes that consumers in the consumption decisions have very important implications as a reference in determining a country's macroeconomic policy. Through marginal propensity to consume (MPC) parameter will be known the magnitude of the coefficient multiplier which in turn will determine the balance of national income, employment, and price level of an economy. By knowing the above parameter governments can take fiscal policy and monetary policy to achieve macroeconomic targets (Burhan, 2005). Household consumption contributed most greatly to the national income. In most countries, consumption spending is $60-70$ percent of the national income. Household consumption patterns have a very important influence in determining fluctuations in economic activity from one time to another time (Sukirno, 2003).

\section{Conclusion}

Based on the results of previous studies that have described and linked to the existing conditions of economic development Riau is seen from the aspect of economic growth, GDP growth Riau and various variables affecting economic growth, especially from the aspect of human resources (SDM), it can be concluded that Comprehensively variable physical investment, human resources (SDM), positive affect household consumption and only natural resource that negatively affect economic growth in the province of Riau. Economic growth in the province of Riau these factors are very suitable due to the interaction between the three main elements in the production system in an area that is available natural resources, human resources (or the population), and the existing stock of capital goods.

\section{References}

[1] Adisasmita, Sakti Adji, Transportasi dan Pengembangan Wilayah (Yogyakarta, Graha Ilmu, 2011).

[2] Arsyad, Lincolin, Ekonomi Pembangunan (Yogyakarta, STIE YKPN, 2004).

[3] Burhan, Umar, Perilaku Rumah Tangga Muslim dalam Menabung, Berinvestasi, dan Menyusun Portofolio Kekayaan dan Implikasinya terhadap Perkembangan Bank Syariah. doctoral diss., Universitas Brawijaya Malang, 2005.

[4] Clark, C, The Conditions of Economic Progress (London, Macmillan \& Co Ltd, 1940) in Hayami, Y, Development Economics: From The Poverty to The Weallth of Nations, Second Edition (New York, Oxford University Press, 2001)

[5] Galor, Oded, and David N. Weil, Population, Technology and Growth: From The Malthusian Regime to the Demographic Transion, American Economic Review, 110 (4), 2000, 806-828.

[6] Kuncoro, Mudrajad, Ekonomika Pembangunan: Teori, Masalah, dan Kebijakan fourth edition (Yogyakarta, UPP AMP YKPN, 2006).

[7] Lucas, R. J, On mechanics of development planning. Journal of Monetary Economics, 22 (1), 1988, 3-42.

[8] Mulyadi, Subari, Ekonomi Sumber Daya Manusia (Jakarta, PT. Raja Grafindo Persada, 2003).

[9] Riduwan and Kuncoro, Engkos Achmad, Cara Menggunakan dan Memaknai Analisa Jalur (Path Analysis) (Jakarta, Alfabeta, 2007).

[10] Romer, David, Endogenous Technological Change, Journal of Political Economy, 98 (2), 1990, 71-102.

[11] Sukirno, Sadono, Ekonomi Pembangunan (Jakarta, Lembaga Penerbit Fakultas Ekonomi Universitas Indonesia with Bina Grafika, 2003).

[12] Todaro, Michael P. Economic Development ${ }^{7}$ th edition (New York, Addison-Wesley, 2000).

[13] Zanden, Jan Luiten Van and Daan Marks, Ekonomi Indonesia 1800-2010: Antara Drama dan Keajaiban Pertumbuhan (Jakarta, Gramedia, 2012). 